\title{
Kepuasan Pasien Rawat Inap Ditinjau dari Kualitas Pelayanan, Harga dan Fasilitas di Lumajang
}

\author{
Sukma Irdiana ${ }^{1}$, Irma Safiyatul Hidayah ${ }^{2}$ \\ Program Studi Manajemen, STIE Widya Gama Lumajang ${ }^{12}$ \\ Email: sukmapasah@gmail.com
}

https://doi.org/10.30741/wiga.v9i1.411

I N F O A R T IKE L

Tanggal masuk :

28 Februari 2019

Tanggal Revisi :

18 Maret 2019

Tanggal Diterima :

31 Maret 2019

\section{A B S T R A K}

Tujuan penelitian ini adalah untuk mengetahui pengaruh kualitas pelayanan, harga dan fasilitas terhadap kepuasan pasien rawat inap kelas III, baik secara parsial maupun secara simultan. Penelitian ini dilakukan di Rumah Sakit Wijaya Kusuma Lumajang. Metode penelitian yang digunakan dalam penelitian ini adalah Regresi Linier Berganda. Hasil penelitian ini menunjukkan bahwa secara parsial variabel kualitas pelayanan berpengaruh signifikan terhadap kepuasan pasien rawat inap kelas III pada Rumah Sakit Wijaya Kusuma Lumajang. Sedangkan untuk variabel harga dan variabel fasilitas tidak berpengaruh signifikan terhadap kepuasan pasien rawat inap kelas III pada Rumah Sakit Wijaya Kusuma Lumajang. Dari hasil secara simultan menunjukkan bahwa variabel kualitas pelayanan, harga dan fasilitas tidak berpengaruh signifikan secara simultan terhadap kepuasan pasien rawat inap kelas III pada Rumah Sakit Wijaya Kusuma Lumajang dengan koefisien determinasi (adjusted $R^{2}$ ) diperoleh sebesar 0,167. Hal ini berarti $16,7 \%$ kepuasan pasien dapat dijelaskan oleh variabel independen yaitu kualitas pelayanan, harga dan fasilitas, sedangkan sisanya yaitu 83,3\% kepuasan pasien dipengaruhi oleh variabel-variabel lainnya yang tidak diteliti dalam penelitian ini. Keterbatasan penelitian ini adalah hanya meneliti pengaruh variabel kualitas pelayanan, harga dan fasilitas terhadap kepuasan pasien, Sedangkan variabel lain yang mempengaruhi kepuasan pasien diharapkan dapat diteliti oleh peneliti selanjutnya.

Kata kunci : kualitas pelayanan, harga, fasilitas, kepuasan pasien. 
satisfaction is influenced by other variables not examined in this study. The limitations of this study are only examining the effect of variable service quality, price and facilities on patient satisfaction, while other variables that influence patient satisfaction are expected to be investigated by future researchers.

Keywords: quality of service, price, facilities, patient satisfaction

\section{PENDAHULUAN}

Dewasa ini dunia kesehatan seperti Rumah Sakit, Puskesmas maupun Klinik-klinik kesehatan mengalami perkembangan yang sangat signifikan dan memiliki prospek yang cukup bagus. Sehingga kondisi seperti ini membuat persaingan menjadi semakin kompetitif. Oleh karena itu setiap perusahaan yang bergerak dalam industri jasa kesehatan harus mampu menggunakan berbagai cara agar dapat menarik pelanggan melalui kualitas pelayanannya. Rumah Sakit sebagai pelayanan kesehatan masyarakat umum, harus memikirkan apakah pelayanan yang diberikan sudah sesuai harapan pasien atau tidak. Oleh karena itu, pihak Rumah Sakit dituntut untuk selalu menjaga kepercayaan pasien dengan cara meningkatkan kualitas pelayanannya. Kualitas pelayanan adalah suatu bentuk pelayanan yang dapat memuaskan para pengguna jasa, baik pelayanan teknis maupun administrasi.

Menurut American Society for Quality Control (Ratnasari dan Aksa, 2011:103-104) menyatakan bahwa "kualitas adalah keseluruhan dari ciri-ciri dan karakteristik-karakteristik dari suatu produk/jasa dalam hal kemampuannya untuk memenuhi kebutuhan-kebutuhan yang telah ditentukan atau bersifat laten, dan dengan kata lain kualitas suatu produk/jasa adalah sejauh mana produk/jasa memenuhi spesifikasi-spesifikasinya". Menurut Azwar (1996), "pelayanan kesehatan yang bermutu adalah pelayanan kesehatan yang dapat memuaskan setiap pemakai jasa pelayanan kesehatan sesuai dengan tingkat kepuasan rata-rata penduduk serta yang penyelenggaraannya sesuai dengan standar dan kode etik profesi yang telah ditetapkan". Kualitas pelayanan terhadap rumah sakit pernah dilakukan oleh Supartiningsih (2017), Surahmawati (2015), Bata, Arifin, dan Darmawansyah (2013), mengatakan bahwa kualitas pelayanan berpengaruh terhadap kepuasan pasien. Hal ini menujukkan bahwa apabila kualitas pelayanan yang diberikan oleh rumah sakit terpenuhi dengan baik maka kepuasan pasien akan terbentuk dari pelayanan yang diberikan.

Selain meningkatkan kualitas pelayanan jasa, Rumah Sakit juga perlu memikirkan tentang harga pelayanannya. Harga adalah suatu nilai yang mempengaruhi jumlah penjualan dan mempunyai peran langsung dalam membentuk nilai bagi pelanggan. Menurut Cannon, Perreault dan McCarthy (2009:176) menyatakan bahwa harga merupakan salah satu dari empat variabel keputusan strategi utama yang dikendalikan oleh manajer pemasaran. Keputusan penetapan harga mempengaruhi jumlah penjualan yang dilakukan oleh perusahaan dan berapa banyak pendapatan yang diperoleh. Harga adalah sesuatu yang harus diberikan oleh pelanggan untuk mendapatkan keunggulan yang ditawarkan oleh bauran pemasaran perusahaan. Jadi, harga memainkan peran langsung dalam membentuk nilai pelanggan.Harga yang ditawarkan haruslah sesuai dengan kemampuan (daya beli) konsumen, karena harga yang tidak sesuai atau terlalu mahal justru akan membuat konsumen pindah ke pelayanan kesehatan lain. Masyarakat umumnya memilih jasa pelayanan kesehatan Rumah Sakit, karena mereka beranggapan bahwa kelengkapan fasilitas dan kualitas pelayanan yang diharapkan sesuai dengan harga yang ditetapkan. Penelitian tentang harga pada rumah sakit telah dilakukan oleh Dumaris (2016), Palupi, Wardhani, dan Andarini (2016), As'ad (2013) mengatakan bahwa harga merupakan salah satu factor terpenting dalam menciptakan kepuasan pasien. Hal ini dikarenakan harga dapat membuat pasien untuk dapat berfikir ulang akan biaya yang akan dikeluarkan dan itu berdampak pada kepuasan pasien. 
Tidak hanya kualitas layanan dan harga, Fasilitas juga merupakan hal terpenting yang harus diperhatikan bagi penyedia jasa layanan kesehatan. Dalam usaha meningkatkan kepuasan, fasilitas berupa sarana dan prasarana sangatlah penting untuk memberikan kemudahan, memenuhi kebutuhan dan kenyamanan bagi pengguna jasa. Apabila fasilitas yang disediakan sesuai dengan kebutuhan, maka konsumen akan merasa puas. Bagi Rumah Sakit keberadaan fasilitas sebagai penunjang pelayanan kesehatan. "Fasilitas adalah desain dan tata letak fasilitas jasa erat kaitannya dengan pembentukan presepsi pelanggan. Sejumlah tipe jasa, presepsi yang terbentuk dari interaksi antara pelanggan dengan fasilitas berpengaruh terhadap kualitas jasa tersebut di mata pelanggan" (Tjiptono 2011:136). Apabila fasilitas jasa tersedia dengan baik dan memadai maka pelayanan yang diberikan oleh rumah sakit dapat optimal. Pasien juga akan merasa terlayani dengan baik sehingga dengan ketersediaan fasilitas yang baik dapat menimbulkan kepuasan pasien. Berdasarkan penelitian yang pernah dilakukan oleh Harfika dan Abdullah (2017), Mongkaren (2013), Indrayani dan Welia (2018) mengatakan bahwa fasilatas berpengaruh terhadap kepuasan pasien. Hal ini dikarenakan fasilitas merupakan salah satu sarana dan prasarana yang sangat dibutuhkan oleh pasien sehingga apabila fasilitas itu terpenuhi maka kepuasan pasien akan rumah sakit tersebut akan tercapai.

Kepuasan pelanggan merupakan salah satu unsur yang sangat penting bagi pelanggan dalam mengkonsumsi suatu jasa. Kepuasan konsumen merupakan syarat yang harus di penuhi perusahaan agar mampu sukses menciptakan dan mempertahankan pelanggan. Sedangkan kepuasan pasien adalah suatu tingkatan dimana antara kebutuhan, keinginan dan harapan dari pasien dapat terpenuhi. Sehingga mengakibatkan pasien akan kembali menggunakan jasa tersebut. Kepuasan pasien atau konsumen berhubungan dengan mutu dari produk yang ditawarkan oleh mereka. Kepuasan konsumen mempunyai tingkatan masing-masing tergantung apa yang mereka peroleh. Beberapa definisi kepuasan menurut para ahli menyatakan bahwa: Kepuasan adalah perasaan senang atau kecewa seseorang yang muncul setelah membandingkan kinerja (hasil) produk yang dipikirkan terhadap kinerja yang diharapkan (Kotler dan Keller, 2007:177). Kepuasan pasien ini pernah dilakukan oleh Supriyanto dan Soesanto (2012), Riswardani (2013), Agung, Muzakir dan Gunawan (2016) mengatakan bahwa kepuasan pasien dapat ditijau dari kualitas pelayanan yang diberikan, fasilitas yang ada dan harga yang dapat pasien bayarkan. Ini semua merupakan satu factor yang dapat membuat pasien puas dalam pelayanan rumah sakit.

Tujuan dalam penelitian ini ditetapkan sebagai berikut: (1) Untuk mengetahui bahwa kualitas pelayanan berpengaruh signifikan terhadap kepuasan pasien rawat inap kelas III pada Rumah Sakit Wijaya Kusuma Lumajang. (2) Untuk mengetahui bahwa harga berpengaruh signifikan terhadap kepuasan pasien rawat inap kelas III pada Rumah Sakit Wijaya Kususma Lumajang. (3) Untuk mengetahui bahwa fasilitas berpengaruh signifikan terhadap kepuasan pasien rawat inap kelas III pada Rumah Sakit Wijaya Kusuma Lumajang. (4) Untuk mengetahui bahwa adanya pengaruh kualitas pelayanan, harga dan fasilitas yang signifikan secara simultan terhadap kepuasan pasien rawat inap kelas III pada Rumah Sakit Wijaya Kusuma Lumajang.

Berdasarkan perumusan masalah dan tujuan dalam penelitian ini, maka hipotesis dikemukakan sebagai berikut: H1: Terdapat pengaruh kualitas pelayanan, harga dan fasilitas secara parsial signifikan terhadap kepuasan pasien rawat inap kelas III pada Rumah Sakit Wijaya Kusuma Lumajang. H2: Terdapat pengaruh kualitas pelayanan, harga dan fasilitas secara simultan signifikan terhadap kepuasan pasien rawat inap kelas III pada Rumah Sakit Wijaya Kusuma Lumajang.

\section{METODE PENELITIAN}

Penelitian ini merupakan penelitian kuantitatif dengan mencari hubungan kausal. "Penelitian ini merupakan penelitian asosiatif yang bersifat kausal, dimana hubungan yang diteliti bersifat sebab akibat" (Sugiyono, 2008:36). "Desain penelitian ini merupakan penelitian penjelasan (explanatory 
research) yaitu menjelaskan hubungan antara satu variabel dengan variabel lainnya" (Umar, 2008:166). Untuk menganalisis variabel independent (X) yang terdiri dari variabel kualitas pelayanan, harga dan fasilitas terhadap kepuasan pasien (Y), maka dalam penelitian ini digunakan teknik analisis regresi linier berganda, dengan teknik tersebut akan dapat diuji hipotesis yang menyatakan ada pengaruh secara parsial dan pengaruh secara simultan antara variabel independen $(\mathrm{X})$ yaitu kualitas pelayanan $\left(\mathrm{X}_{1}\right)$, harga $\left(\mathrm{X}_{2}\right)$ dan fasilitas $\left(\mathrm{X}_{3}\right)$ terhadap variabel dependen $(\mathrm{Y})$ yaitu kepuasan pasien.

Penelitian ini populasinya sebanyak 40 pasien adalah semua pasien rawat inap kelas III pada rumah sakit Wijaya kusuma Lumajang. Sampel dalam penelitian ini adalah seluruh pasien rawat inap kelas III pada rumah sakit Wijaya Kusuma Lumajang. Teknik pengambilan sampel yang digunakan dalam penelitian ini diambil secara Probability Sampling, dan teknik yang dipilih yaitu Simple Random Sampling, menurut Sugiyono (2012:118 ) menyatakan bahwa "Simpel Random Sampling merupakan teknik pengambilan sampel yang memberikan peluang yang sama bagi setiap unsur (anggota) populasi untuk dipilih menjadi anggota sampel". "Sesuai dengan hipotesis dan tujuan yang ingin dicapai dalam penelitian, maka digunakan analisis regresi linier berganda dengan bentuk hubungan assosiatif kausal, yang digunakan untuk mengetahui pengaruh variabel independen dalam memprediksi variabel dependen dalam penelitian ini" (Sugiyono, 2009:35). Sebelum dilakukan analisis dan uji pengaruh, maka terhadap kuesioner perlu dilakukan uji validitas dan reliabilitas. Selanjutnya akan dilakukan analisis dan uji pengaruh yang menggunakan asumsi dasar regresi linier berganda bahwa data harus berdistribusi normal, terbebas dari Multikolinieritas (Multicolonearity) dan Heterokedastisitas (Heterokedasticity).

Pengujian validitas penelitian ini mempergunakan analisis korelasi Product Moment, dengan mengkolerasikan skor setiap item dengan skor total sebagai jumlah skor item. Menurut Sugiyono (2012:178), analisa faktor dilakukan dengan cara mengkorelasi jumlah skor faktor dengan skor total. Bila korelasi tiap faktor tersebut positif dan besarnya 0,3 ke atas maka faktor tersebut merupakan construct yang kuat. Dalam penelitian ini jika korelasi antara skor butir dengan skor total kurang dari 0,3 maka butir-butir dalam instrumen tersebut dinyatakan tidak valid. Menurut Fuad Mas'ud (2004:69), reliabilitas atau tingkat keandalan, ketetapan atau keajegan (consistencykonsistensi) adalah tingkat kemampuan instrumen riset untuk mengumpulkan data secara konsisten dari sekelompok individu. Instrumen yang mempunyai tingkat reliabilitas tinggi cenderung menghasilkan data yang sama tentang suatu variabel atau unsur-unsurnya, jika diulangi pada waktu yang berbeda pada pada sekelompok individu yang sama. Sehingga instrumen tersebut dapat dinilai reliabel (dapat diandalkan).

Uji normalitas untuk mengetahui apakah variabel dependen, independen atau keduanya berdistribusi normal, mendekati normal atau tidak. Model regresi yang baik hendaknya berdistribusi normal atau mendekati normal. Medeteksi apakah data berdistribusi normal atau tidak dapat diketahui dengan menggambarkan penyebaran data melalui sebuah grafik. Jika data menyebar di sekitar garis diagonal dan mengikuti arah garis diagonalnya, model regresi memenuhi asumsi normalitas. (Umar, 2011:181). Untuk mengetahui data tersebut memenuhi syarat atau tidak multikolinieritas adalah dengan melihat output SPSS pada table coefficients jika nilai VIF (Variance Inflation Factor) di bawah angka $10(\mathrm{VIF}<10)$ berarti tidak terjadi multikolinieritas" (Sugiyono, 2009:139). Uji heteroskedastisitas dilakukan untuk mengetahui apakah dalam sebuah model regresi terjadi ketidaksamaan varians dari residual suatu pengamatan ke pangamatan lain. Jika varians dari residual suatu pengamatan ke pengamatan lain tetap, disebut homoskedastisitas, sementara itu, untuk varians yang berbeda disebut heteroskedastisitas. Model regresi yang baik adalah tidak terjadi heteroskedastisitas. (Umar, 2011:179).

Analisis regresi ganda digunakan oleh peneliti, bila peneliti bermaksud meramalkan bagaimana keadaan (naik turunnya) variabel dependen (kriterium), bila dua atau lebih variabel independen sebagai faktor prediktor dimanipulasi (dinaik turunkan nilainya). Jadi analisis regresi ganda akan 
dilakukan bila jumlah variabel independennya minimal dua. (Sugiyono, 2012:277). Persamaan regresinya adalah:

$Y=a+\beta_{1} X_{1}+\beta_{2} X_{2}+\beta_{3} X_{3}$

Keterangan :

$\mathrm{Y}=$ variabel dependen yaitu kepuasan pasien

$\mathrm{X}=$ variabel independen

$\mathrm{X}_{1}=$ variabel kualitas pelayanan

$\mathrm{X}_{2}=$ variabel harga

$\mathrm{X}_{3}=$ variabel fasilitas

$\mathrm{a}=$ konstanta

$\beta=$ koefisien regresi variabel independen

Dengan analisis regresi berganda ini juga dapat diketahui variabel mana di antara variabel independen yaitu harga dan kualitas pelayanan yang berpengaruh dominan terhadap variabel dependen yaitu kepuasan pelanggan. Analisis regresi linier berganda juga dapat digunakan untuk mengetahui seberapa besar hubungan masing-masing independen terhadap variabel independen lainnya. Untuk mengetahui variabel independen yang dominan pengaruhnya terhadap variabel dependen, ditunjukkan dengan koefisien regresi $(\beta)$ yang sudah distandardisasi yaitu nilai beta. (Hastono, 2006:6). Setelah dilakukan analisis regresi linier berganda kemudian dilakukan pengujian hipotesis yang digunakan untuk mengetahui apakah ada pengaruh antara variabel independen (kualitas pelayanan, harga dan fasilitas) terhadap variabel dependen (kepuasan pasien), baik secara parsial maupun secara simultan. Serta manakah diantara variabel independen yang mempunyai dominan terhadap variabel dependen.

"Uji t digunakan untuk mengetahui pengaruh variabel bebas yaitu harga dan kualitas pelayanan terhadap variabel terikat yaitu kepuasan pelanggan secara parsial yang di uji dengan cara signifikan” (Mudrajat Kuncoro, 2007:81). “Uji F digunakan untuk mengetahui pengaruh variabel bebas yaitu harga dan kualitas pelayanan secara simultan terhadap variabel terikat yaitu kepuasan pelanggan yang di uji dengan cara uji signifikan" (Menurut Mudrajat Kuncoro, 2007:82). Koefisien determinasi $\left(\mathrm{R}^{2}\right)$ dimaksudkan untuk mengetahui tingkat ketepatan yang paling baik dalam analisa regresi, hal ini ditunjukkan oleh besarnya koefisien determinasi $\left(\mathrm{R}^{2}\right)$ antara 0 (nol) sampai dengan 1 (satu). Menurut Singgih Santoso (2012:355), untuk melihat koefisien determinasi pada regresi linier berganda adalah dengan menggunakan nilai $R$ Square. Dari koefisien determinasi $\left(\mathrm{R}^{2}\right)$ ini dapat diperoleh suatu nilai untuk mengukur besarnya sumbangan dari beberapa variabel $\mathrm{X}$ terhadap variasi naik turunnya variabel $\mathrm{Y}$ yang biasanya dinyatakan dalam prosentase.

\section{HASIL DAN PEMBAHASAN}

Responden dalam penelitian ini adalah pasien rawat inap kelas III yang melakukan perawatan kesehatan pada rumah sakit Wijaya Kusuma Lumajang. Adapun jumlah responden yang diambil sebagai sampel penelitian sebanyak 40 pasien. Hasil dari deskripsi responden menurut jenis kelamin menunjukkan bahwa dari 40 responden, 18 orang atau 45\% diantaranya adalah laki-laki dan sisanya sebanyak 22 orang atau 55\% adalah perempuan. Data ini menunjukkan bahwa pasien perempuan yang mendominasi melakukan perawatan kesehatan pada rawat inap kelas III rumah sakit Wijaya Kusuma Lumajang. Hasil dari deskripsi responden berdasarkan usia menunjukkan bahwa dari 40 responden, 3 orang atau 7,5\% adalah usia kurang dari 10 tahun. 7 orang atau 17,5\% adalah usia 11-20 tahun. 20 orang atau 50\% adalah usia 21-30 tahun. 6 orang atau 15\% adalah usia 31-40 tahun. 1 atau 2,5\% adalah usia 41-50 tahun. 3 atau 7,5\% adalah usia lebih dari 50 tahun. Data ini menunjukkan bahwa responden usia 21-30 tahun yang mendominasi melakukan perawatan kesehatan pada rawat inap kelas III rumah sakit Wijaya Kusuma Lumajang. Pengumpulan data penelitian dilakukan dengan cara memberikan kuesioner kepada 40 responden penelitian. Rincian perolehan kuesioner dalam penelitian ini dapat dilihat pada lampiran 
rekapitulasi data. Untuk selanjutnya data yang sudah terkumpul dianalisis dengan bantuan program komputer SPSS for Windows Release 16.0.

Pada variabel kualitas pelayanan terdapat butir pertanyaan yang tidak valid yaitu pada butir pertanyaan kelima dan butir pertanyaan keempat. Oleh karena itu perlu dilakukan pengujian validitas ulang dengan mengeluarkan item kuesioner yang tidak valid yaitu X1.5 dan X1.4. selain itu pada variabel fasilitas juga terdapat butir pertanyaan yang tidak valid yaitu pada butir pertanyaan ketiga, perlu dilakukan pengujian validitas ulang dengan mengeluarkan item kuesioner yang tidak valid yaitu X3.3. Besarnya koefisien korelasi dari seluruh butir pertanyaan yang terdiri dari masing-masing 3 (tiga) butir pertanyaan untuk variabel kualitas pelayanan, 4 (lima) butir pertanyaan untuk variabel harga, 5 (lima) butir pertanyaan untuk variabel fasilitas dan 5 (lima) butir pertanyaan untuk variabel kepuasan pasien. Dari hasil perhitungan koefisien korelasi, seluruhnya mempunyai $r$ hitung yang lebih besar dari $r$ minimal $(0,3)$. Dengan demikian bahwa seluruh butir pertanyaan dinyatakan valid. Kesimpulannya seluruh butir pertanyaan yang ada pada instrumen penelitian dapat dinyatakan layak sebagai instrumen penelitian karena dapat menggali data atau informasi yang diperlukan.

Tabel 1. Uji Reliabilitas

\begin{tabular}{llll}
\hline $\begin{array}{l}\text { Cronbach' } \\
\text { S Alpha }\end{array}$ & Variabel & Interval Reliabilitas & Keterangan \\
\hline 0,823 & Kualitas Pelayanan (X1) & $0,801-1,00$ & Sangat Reliabel \\
0,782 & Harga (X2) & $0,601-0,80$ & Reliabel \\
0,740 & Fasilitas (X3) & $0,601-0,80$ & Reliabel \\
0,751 & Kepuasan Pasien (Y) & $0,601-0,80$ & Reliabel \\
\hline
\end{tabular}

Suatu model regresi yang baik harus bebas dari masalah penyimpangan terhadap asumsi klasik atau asumsi dasar. Berikut ini adalah hasil pengujian terhadap asumsi klasik atau asumsi dasar dalam model regresi linier berganda. Distribusi yang normal memiliki bentuk yang simetris dengan nilai mean, median, dan mode yang mengumpul di satu titik tengah. Hasil pengujian tersebut menunjukkan bahwa dari 40 responden diperoleh nilai mean sebesar -1,08 dengan standart deviasi 0,961 dan titik puncak tepat berada di titik tengah atau tepat di angka 0 . Hal ini berarti model regresi tersebut sudah berdistribusi normal. Jika nilai-nilai sebaran data terletak disekitar garis lurus diagonal maka persyaratan normalitas terpenuhi. (Singgih Santoso, 2012:361). Hasil pengujian tersebut menunjukkan bahwa titik-titik berada tidak jauh dari garis diagonal, hal ini berarti bahwa model regresi tersebut sudah berdistribusi normal.

Tabel 2. Hasil Uji Multikolinieritas

\begin{tabular}{lccc}
\hline \multicolumn{1}{c}{ Variabel } & Tolerance & VIF & Keterangan \\
\hline $\begin{array}{l}\text { Kualitas } \\
\text { Pelayanan }\end{array}$ & 0,707 & 1,415 & Bebas Multikolinearitas \\
$\begin{array}{l}\text { X1) } \\
\text { Harga (X2) }\end{array}$ & 0,691 & 1,447 & Bebas Multikolinearitas \\
Fasilitas (X3) & 0,890 & 1,123 & Bebas Multikolinearitas \\
\hline
\end{tabular}

Hasil pengujian menunjukkan bahwa semua variabel yang digunakan sebagai prediktor model regresi menunjukkan nilai VIF yang cukup kecil, dimana semuanya berada di bawah 10 dan nilai tolerance lebih dari 0,1. Hal ini berarti bahwa variabel independen yang digunakan dalam penelitian tidak menunjukkan adanya gejala multikolinieritas, jadi semua variabel independen dalam penelitian ini adalah variabel yang saling independen, sehingga dapat dilanjutkan dalam pengujian regresi linier berganda. 
Hasil pengujian heteroskedastisitas menunjukkan tidak terdapat pola yang jelas dari titik-titik tersebut. Hal ini menunjukkan bahwa model regresi tidak memiliki gejala adanya heteroskedastisitas, yang berarti bahwa tidak ada gangguan yang berarti dalam model regresi ini.

Model persamaan regresi dari tabel dapat dituliskan dalam bentuk persamaan regresi Unstandardized coefficients adalah sebagai berikut: $\mathrm{Y}=30,424-0,586 \mathrm{X}_{1}-0,076 \mathrm{X}_{2}-0,013 \mathrm{X}_{3}$

Secara keseluruhan hasil penelitian ini menunjukkan bahwa kondisi penilaian responden terhadap variabel-variabel penelitian ini sebagian besar menyatakan persetujuannya. Dari banyaknya tanggapan kesetujuan yang tinggi dari para responden terhadap kondisi dari masing-masing variabel penelitian. Dari hasil tersebut diperoleh bahwa variabel independen yaitu kualitas pelayanan berpengaruh signifikan terhadap kepuasan pasien, harga tidak berpengaruh signifikan terhadap kepuasan pasien, dan fasilitas tidak berpengaruh signifikan terhadap kepuasan pasien.

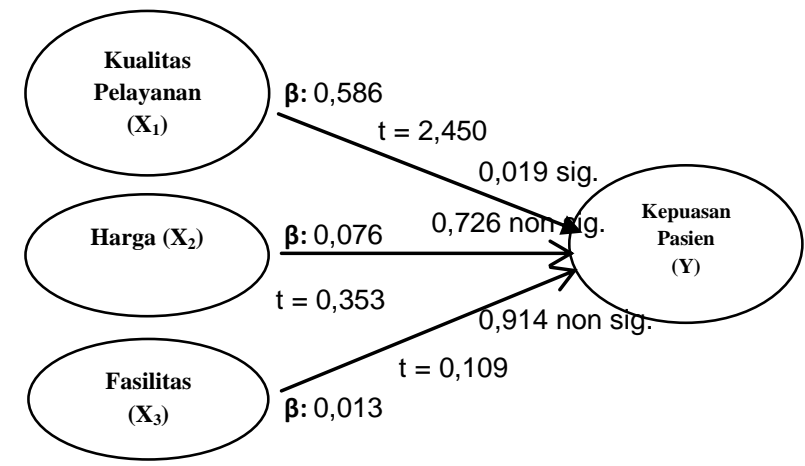

Gambar 1. Model Penelitian

Hasil uji $\mathrm{F}$ pada variabel penelitian diperoleh nilai $\mathrm{F}$ hitung $=2,409$ dengan tingkat signifikansi 0,083. Dengan menggunakan batas signifikansi 5\% atau 0,05, diperoleh $\mathrm{F}$ tabel sebesar 2,866. Ini berarti $\mathrm{F}$ hitung < F tabel, yang berarti Ho diterima dan Ha ditolak. Dengan tingkat signifikansi 0,083 yang berada di bawah batas signifikansi 0,05 maka dapat disimpulkan bahwa tidak terdapat pengaruh kualitas pelayanan, harga dan fasilitas yang signifikan secara simultan terhadap kepuasan pasien rawat inap kelas III pada Rumah Sakit Wijaya Kusuma Lumajang.

Dari hasil perhitungan dengan menggunakan program SPSS dapat diketahui bahwa koefisien determinasi (R Square) yang diperoleh sebesar 0,167. Hal ini berarti 16,7\% kepuasan pasien dapat dijelaskan oleh variabel independen yaitu kualitas pelayanan, harga dan fasilitas, sedangkan sisanya yaitu $83,3 \%$ kepuasan pasien dipengaruhi oleh variabel-variabel lainnya yang tidak diteliti dalam penelitian ini.

\section{HASIL DAN PEMBAHASAN}

Petugas Rumah Sakit Wijaya Kusuma dalam memberikan pelayanan kepada pasien sesuai dengan SOP (Standart Operasional Prosedur) Rumah Sakit. Penilaian terhadap kualitas pelayanan mempunyai kecenderungan nilai yang tinggi. Ini menunjukkan bahwa kualitas pelayanan merupakan hal yang penting bagi pasien yang melakukan perawatan kesehatan pada rawat inap kelas III rumah sakit Wijaya Kusuma Lumajang. Rumah Sakit perlu mengetahui bagaimana cara melayani pasien yang efektif dan cepat. Serta perlu memberikan pelayanan yang sesuai dengan yang diharapkan pasien. Dengan pelayanan yang sesuai maka harapan pasien terhadap pelayanan suatu jasa dapat terpenuhi atau bahkan melebihi harapannya, sehingga menimbulkan kepuasan dalam diri pasien. Persepsi kualitas bukan berada pada pandangan penyedia jasa kesehatan namun 
terletak pada diri pasien. Apabila pelayanan yang diterima oleh pasien sesuai dengan yang di harapkan maka pelayanan tersebut dapat dikatakan baik.

Hasil tanggapan responden mengenai harga yang ditawarkan Rumah Sakit Wijaya Kusuma terjangkau memiliki hasil rata-rata rendah. Penilaian terhadap harga mempunyai kecenderungan nilai yang tinggi. Harga yang ditawarkan haruslah sesuai dengan kemampuan pasien, karena harga yang tidak sesuai atau terlalu mahal justru akan membuat pasien pindah ke pelayanan kesehatan lain. Masyarakat umumnya memilih jasa pelayanan kesehatan Rumah Sakit, karena mereka beranggapan bahwa kelengkapan fasilitas dan kualitas pelayanan yang diharapkan sesuai dengan harga yang ditetapkan. Masyarakat berpikir bahwa Rumah Sakit dapat memberikan pelayanan kesehatan yang mudah, murah, dan efisien. Harga sangatlah berpengaruh apabila harga yang ditawarkan terlalu mahal maka banyak pasien yang akan mengeluh. Selain itu harga yang mahal juga akan membuat persepsi pasien meningkatkan harapan terhadap kualitas layanan yang mereka terima akan semakin baik. Jika harapan tersebut tidak dapat dipenuhi oleh rumah sakit maka pasien akan kecewa lalu menimbulkan keluhan.

Hasil tanggapan responden mengenai apakah pembuangan limbah ruang inap kelas III berpengaruh terhadap lingkungan sekitar Rumah Sakit memiliki hasil rata-rata rendah. Ini menunjukkan bahwa fasilitas merupakan hal yang penting yang harus diperhatikan bagi rumah sakit Wijaya Kusuma Lumajang. Dalam usaha meningkatkan kepuasan, fasilitas berupa sarana dan prasarana sangatlah penting untuk memberikan kemudahan, memenuhi kebutuhan dan kenyamanan bagi pasien. Apabila fasilitas yang disediakan sesuai dengan kebutuhan pasien, maka pasien akan merasa puas. Bagi Rumah Sakit keberadaan fasilitas sebagai penunjang pelayanan kesehatan, keberadaan fasilitas seperti kotak saran dan keluhan akan membantu Rumah Sakit dalam memperoleh informasi mengenai hal-hal apa saja yang diinginkan dan menjadi kebutuhan pasien. Serta Rumah Sakit akan memperoleh informasi mengenai hal-hal apa saja yang perlu dibenahi dari pihak Rumah Sakit. Dengan demikian pasien akan lebih mudah menyampaikan hal yang menjadi ketidakpuasannnya dalam memperoleh pelayanan.

Hasil pengujian variabel yang terdiri dari kualitas pelayanan, harga dan fasilitas secara simultan atau bersama-sama terhadap kepuasan pasien menunjukkan bahwa secara simultan variabel yang terdiri dari kualitas pelayanan, harga dan fasilitas tidak berpengaruh terhadap kepuasan pasien. berdasarkan koefisien determinasi ( $\mathrm{R}$ Square) sebesar 0,167 menunjukkan bahwa kualitas pelayanan, harga dan fasilitas secara simultan atau bersama-sama tidak berpengaruh terhadap kepuasan pasien sebesar 16,7\%. sedangkan sisanya sebesar 83,3\% kepuasan pasien dipengaruhi oleh variabel-variabel lainnya yang tidak diteliti dalam penelitian ini. Pada dasarnya pelayanan rumah sakit diperlukan oleh setiap orang untuk keperluan kesehatannya, maka diharapkan kualitas pelayanan yang baik dapat menumbuhkan dan mempengaruhi keputusan serta kepercayaan pasien demi menimbulkan kepuasan pasien untuk menggunakan jasa layanan kesehatan. Kepuasan pasien merupakan salah satu unsur yang sangat penting bagi pasien dalam menggunakan jasa perawatan kesehatan pada sebuah Rumah Sakit. Kepuasan pasien merupakan syarat yang harus di penuhi oleh Rumah Sakit agar mampu sukses menciptakan dan mempertahankan citra Rumah Sakit.

\section{KESIMPULAN}

Penelitian ini bertujuan untuk mengetahui pengaruh kualitas pelayanan, harga dan fasilitas terhadap kepuasan pasien rawat inap kelas III pada Rumah Sakit Wijaya Kusuma Lumajang baik secara parsial maupun simultan dengan menggunakan teknik analisis regresi linier berganda. Dari perumusan masalah, tujuan dan hipotesis penelitian serta pembahasan hasil penelitian yang telah dikemukakan pada bab sebelumnya dapat ditarik beberapa kesimpulan dari penelitian ini sebagai berikut: (1) Hasil pengujian hipotesis atas pengaruh kualitas pelayanan terhadap kepuasan pasien menunjukkan adanya pengaruh kualitas pelayanan terhadap kepuasan pasien rawat inap kelas III Rumah Sakit Wijaya Kusuma Lumajang. (2) Hasil pengujian hipotesis atas pengaruh harga 
terhadap kepuasan pasien menunjukkan tidak terdapat pengaruh harga terhadap kepuasan pasien rawat inap kelas III Rumah Sakit Wijaya Kusuma Lumajang. (3) Hasil pengujian hipotesis atas pengaruh fasilitas terhadap kepuasan pasien menunjukkan tidak terdapat pengaruh fasilitas terhadap kepuasan pasien rawat inap kelas III Rumah Sakit Wijaya Kusuma Lumajang. (4) Hasil pengujian atas pengaruh kualitas pelayanan, harga dan fasilitas secara simultan terhadap kepuasan pasien, ini menunjukkan bahwa secara simultan kualitas pelayanan, harga dan fasilitas berpengaruh signifikan terhadap kepuasan pasien rawat inap kelas III Rumah Sakit Wijaya Kusuma Lumajang. (5) Hasil koefisien determinasi menunjukkan bahwa sebesar 16,7\% kepuasan pasien dapat dijelaskan oleh variabel independen yaitu kualitas pelayanan, harga dan fasilitas, sedangkan sisanya yaitu $83,3 \%$ kepuasan pasien dipengaruhi oleh variabel-variabel lainnya yang tidak diteliti dalam penelitian ini.

Berdasarkan kesimpulan yang diperoleh dalam penelitian ini, maka diberikan saran-saran sebagai pelengkap terhadap hasil penelitian yang diberikan sebagai berikut: Kualitas pelayanan berpengaruh terhadap kepuasan pasien, oleh karena itu disarankan kepada Rumah Sakit Wijaya Kusuma Lumajang untuk bisa mempertahankan dan meningkatkan kualitas pelayanannya, agar kepercayaan pasien terhadap pelayanan jasa kesehatan pada Rumah Sakit Wijaya Kusuma tetap terjaga dan dapat kembali menggunakan jasa rumah sakit Wijaya Kusuma apabila sakit. Peneliti lain yang ingin melakukan penelitian lebih lanjut tentang kepuasan pasien harus dapat mengembangkan penelitiannya dengan variabel yang berbeda dari peneliti yaitu selain variabel kualitas pelayanan, harga dan fasilitas, karena penelitian ini hanya sebagai tambahan referensi dan informasi agar peneliti lain dapat lebih mengembangkan penelitiannya.

\section{DAFTAR PUSTAKA}

As'ad, A. S. dan Noermijati. (2013). Pengaruh Kualitas Pelayanan dan Harga Terhadap Kepuasan dan Loyalitas Pelanggan (Studi Pada Pasien Rawat Inap di Rumah Sakit NU Tuban). Jurnal Aplikasi Manajemen. Vol 11, No. 3.

Agung, M. dkk. (2016). Pengaruh Kualitas Pelayanan Keperawatan, Fasilitas dan Minat Terhadap Kepuasan Pasien Di Ruang Rawat Inap RSU Wisata UIT Makasar. Jurnal Mirai Management. Vol. 1, No. 2. Hal. 30-44.

Azwar, A. (1996). Menjaga Mutu Pelayanan Kesehatan. Sinar Harapan. Jakarta.

Bata, Y. W., dkk. (2013). Hubungan Kualitas Pelayanan Kesehatan Dengan Kepuasan Pasien Pengguna Akses Sosial PAda Pelayanan Rawat Inap Di RSUD Lakipadada Kabupaten Tana Toraja. Jurnal Bagian Adminstrasi dan Kebijakan Kesehatan Fakultas Kesehatan Masyarakat Universitas Hasanuddin.

Cannon, dkk. (2009). Pemasaran Dasar Pendekatan Manajerial Global. Buku Dua. Edisi Enam Belas. Salemba Empat: Jakarta. Jurnal ARSI. Vol 3, No. 1. Hal : 20-28.

Dumaris. (2016). Analisis Perbedaan Tarif Rumah Sakit dan Tarif INA-CBG's Pelayanan Rawat Jalan di RSUD Budhi Asih Jakarta Tahun 2015.

Harfika, J., dkk. (2017). Pengaruh Kualitas Pelayanan dan Fasilitas Terhadap Kepuasan Pasien Pada Rumah Sakit Umum Kabupaten Aceh Barat Daya. Balance. Vol. XIV, No. 1. Hal : 44-56

Kotler, P. dan Kevin, L. K. (2008). Manajemen Pemasaran. Edisi Tiga Belas. Jilid Satu. Erlangga: Jakarta.

Kuncoro, M. (2007). Metode Kuantitatif Teori dan Aplikasi Untuk Bisnis. Edisi Ketiga. Unit Penerbit dan Percetakan (UPP) STIM KYPN: Yogyakarta.

Mas'ud, F. (2004). Survai Diagnosis Organisasional Konsep dan Aplikasi. Badan Penerbit Universitas Diponegoro: Semarang.

Mongkaren, S. (2013). Fasilitas dan Kualitas Pelayanan Pengaruhnya Terhadap Kepuasan Pengguna Jasa Rumah Sakit Advent Menado. Jurnal EMBA. Vol. 1 No. 4.

Palupi, J. K. N., dkk. (2016). Determinan Pilihan Naik Kelas Perawatan Rumah Sakit dari Kelas I Ke Kelas VIP. Jurnal Kebijakan Kesehatan Indonesia. Vol. 5, No. 4. Hal : 176-183. 
Ratnasari, R. T. dan Mastuti H. A. (2011). Teori dan Kasus - Manajeman Pemasaran Jasa. Ghalia Indonesia: Bogor. Daya Saing Jurnal Ekonomi Manajemen Sumber Daya. Vol. 14, No. 2. Hal. 88-98.

Riswardani, Y. T. S. (2013). Pengaruh Fasilitas, Biaya dan Proosi Terhadap Kepuasan Pasien Rawat Inap.

Santoso, S. (2012). Metodologi Penelitian. PT Bumi Aksara: Jakarta.

Sugiyono. (2008). Metode Penelitian Kuantitaif, Kualitatif dan R \& D. Alfabeta: Bandung.

Sugiyono, (2012). Metode Penelitian Bisnis. Alfabeta: Bandung.

Supartiningsih, S. (2017). Kualitas Layanan Kepuasan Pasien Rumah Sakit : Kasus Pada Pasien Rawat Jalan. Jurnal Medicoeticolegal dan Manajemen Rumah Sakit, Vol. 6, No. 1. Hal : 915.

Supriyanto, Y, dkk. (2012). Analisis Pengaruh Kualitas Pelayanan, Harga, dan Fasilitas Terhadap Kepuasan Pasien Rawat Jalan Di Rumah Sakit Kariadi Semarang. Diponegoro Kournal Of Management. Vol 1, No. 1. Hal. 472-480.

Surahmawati. (2015). Kualitas Pelayanan Kesehatan di Rumah Sakit Umum Daerah Barru (Kasus Pelayanan Rawat Jalan Pasien Pengguna Asuransi Kesehatan). Al-Sihah : Public Health Science Journal. Vol. 7, No. 1. Hal : 26-40.

Sutanto, H. P. (2006). Metode Penelitian Bisnis. Alfabeta: Bandung.

Tjiptono, F. dan G. Chandra. (2011). Service, Quality, \& Satisfaction. Edisi 3. Andi: Yogyakarta.

Umar, H. (2011). Metode Penelitian untuk Skripsi dan Tesis Bisnis. Edisi Dua. PT. Raja Grafindo Persada: Jakarta. 